\section{Vegetative Growth and Leaf Nutrient Status of 'Carpino' Chrysanthemum on a Pecan Wood-amended Commercial Substrate}

\author{
Geno A. Picchioni ${ }^{3}$ \\ Department of Plant and Environmental Sciences, New Mexico State \\ University, Las Cruces, NM 88003
}

\author{
Sharon A. Martinez ${ }^{1}$ \\ Department of Entomology, Plant Pathology, and Weed Science, New \\ Mexico State University, Las Cruces, NM 88003
}

\author{
John G. Mexal' \\ Department of Plant and Environmental Sciences, New Mexico State \\ University, Las Cruces, NM 88003
}

\section{Dawn M. VanLeeuwen \\ Department of Economics, Applied Statistics, and International Business, New Mexico State University, Las Cruces, NM 88003}

Additional index words. Dendranthema $\times$ grandiflorum, Carya illinoinensis, soluble fertilizer, microbial immobilization, fungi, Pleurotus sp., leaching losses, peatmoss, evapotranspiration

\begin{abstract}
Commercial production of pecan [Carya illinoinensis (Wangenh.) K. Koch.] generates significant woody biomass from hedge prunings with little economic value. Value-added uses could aid pecan growers, and one possible use is wood chips for potting substrates to lessen dependence on peatmoss, thereby aiding greenhouse growers. We evaluated vegetative growth and leaf nutrient responses of 'Carpino' garden chrysanthemum (Dendranthema $\times$ grandiflorum) over a 60-day period. Plants were grown in five pecan wood chip substrate levels that substituted $0 \%, 25 \%, 50 \%, 75 \%$, and $100 \%$ of peatmoss by volume. Three water soluble fertilizer (WSF) rates- $N$ at 0,200 , or $400 \mathrm{mg} \cdot \mathrm{L}^{-1}$ $(0-\mathrm{N}, 200-\mathrm{N}$, and 400-N, respectively) - were applied with each irrigation and to each of the wood substitution treatments. The WSF and wood substitution treatments interacted strongly. In the presence of wood, $(25-100 \%$ substitution levels), increasing WSF to $400-\mathrm{N}$ increased cumulative evapotranspiration (ET), crop height, total leaf number and area, total leaf and stem dry weight, and leaf $N$ and $P$ concentrations. However, with $0 \%$ wood substitution, $400-\mathrm{N}$ provided little or no such enhancements. With $25 \%$ to $50 \%$ wood substitution, root dry weight increased by $61 \%$ to $91 \%$ from $0-\mathrm{N}$ to $200-\mathrm{N}$, which may be an adaptive response to nutrient-limiting conditions at 200-N. Appearance of a white rot fungal species in and atop pecan wood-supplemented substrate supports the likelihood that microbial activity was, at least in part, responsible for the nutrient limitations. High WSF at $400-\mathrm{N}$ in combination with $25 \%$ pecan wood substitution maintained adequate fertility and shoot growth that was comparable to the conventional peat-only substrate at $200-\mathrm{N}$. With low to moderate amounts of pecan wood, further adjustments to WSF rate and irrigation volume would support sustainable fertigation practices, reduce dependence on peatmoss by greenhouse industry, and provide a value-added recycling option for pecan growers.
\end{abstract}

Recent concerns over peatmoss availability, cost, and harvest restrictions have created the need for alternative substrates for potted production of ornamental greenhouse and nursery crops (Jackson et al., 2008; Kuack, 2014; Taylor et al., 2012; Wright and Browder, 2005). Chipped wood from softwood trees has shown excellent potential to supplement peatmoss supplies with few changes in production practices (Boyer et al., 2012a; Murphy et al., 2011). Pine wood substrate studies on ornamental crops have revealed limitations of the wood use, particularly reductions in substrate water and nutrient holding capacities a higher proportion of relatively rapidly degradable $\mathrm{C}$ at the expense of substrate fertility due to higher collateral nutrient demands of microorganisms. Hardwood chips may thus be less satisfactory for substrates than softwood chips because of their decomposition rate and nutrient immobilization (Nelson, 2012). Murphy et al. (2011) compared effects of hardwood and softwood chips in potting substrates on growth of several herbaceous ornamental species and their findings supported the unfavorable prognosis for use of hardwood chips.

In Fall 2012, we completed a pilot study at two nearby commercial greenhouse and nursery production sites using various rates of pecan wood chips in the substrate, prepared as described below for the present investigation. A pecan wood chip incorporation rate as low as $25 \%$ (peatmoss or pine bark substitution by volume) reduced total plant dried biomass of 'Step' pot chrysanthemum by $49 \%$ after 2.5 months, and by $21 \%$ in a hybrid lantana (Lantana L. 'New Gold') and a hybrid trailing rose (Rosa L. 'Red Cascade') after 6 months. These plants were subjected to only one fertilization regime, opening the possibility for further study to address the effects of fertilizer rate on crop performance. Reports on pine wood substrate have shown that increasing fertilizer rate is necessary to overcome growth-related suppressions of the wood (Jackson et al., 2008; Wright and Browder; 2005; Wright et al., 2006, 2008). Still et al. (1972) reported that the visual appearance of pot chrysanthemum shoots on a substrate amended with aged sawdust from white oak trees (Quercus alba L.) (33\% to $50 \%$ by volume) compared favorably to that on a conventional peat-only substrate, provided that soluble fertilizer rates were increased accordingly. However, similar data are lacking to support or disqualify the use of hardwood chips in greenhouse potting substrates, particularly in view of what appear to be small differences in lignin concentrations between hardwoods and softwoods noted previously.

New Mexico pecan acreage has increased rapidly (U.S. Department of Agriculture, 2015a) and the state recently ranked second in the United States in total pecan production and economic value (U.S. Department of Agriculture-NASS, 2015b). Doña Ana County has the highest concentration of pecan farms in New Mexico and thus has an important impact on U.S. pecan production (Lillywhite et al., 2007). As pecan trees mature, pruning becomes essential to maintain crop productivity and quality (Picchioni et al., 2000a). Over the last decade, annual hedge pruning has become common in New Mexico pecan orchards with increased availability of equipment and positive effects on annual productivity (R.J. Heerema, personal communication). Kallestad et al. (2008) determined that as many as $\approx 38,000$ t of dry prunings are generated annually in the Mesilla Valley of Doña Ana County where there are also greenhouse and nursery producers. A similar scenario applies throughout the entire southern United States, where 
pecan production is regionally aligned with significant greenhouse and nursery production.

In the Mesilla Valley, pecan prunings have traditionally been disposed of by burning, but a relatively new practice is mechanical shredding for orchard mulch (Kallestad et al., 2008) or tillage to a shallow soil depth (Tahboub et al., 2007). The tillage does not appear to immobilize soil nutrients and may improve soil tilth and aggregation (Tahboub et al., 2007, 2008). Mulching and tillage have provided an environmentally acceptable means of branch disposal in view of recent burning restrictions, but add to pecan production costs.

Recycling hedged pecan wood in potting substrates could provide a value-added revenue stream for pecan growers while aiding their greenhouse and nursery production neighbors seeking alternative substrate components. This practice would be free of the problems associated with widespread adoption of substrate alternatives, such as lack of local availability, high transportation costs, irregular and nonrenewable supplies, and inconsistent quality (Fain et al., 2008; Wright et al., 2008).

Research is needed to determine growth and performance of potted plants in response to pecan wood-amended substrates, particularly for how fertilization practices should be modified to address potential nutrient limitations. In this study, we selected garden chrysanthemum as a vegetative growth model as it represents a traditional greenhouse crop with high nutrient demands (Cavins et al., 2000; Nau, 2011; Wright et al., 2008). In light of nutrient limitations reported in pine-based substrates and our preliminary findings on pecan wood, we hypothesized: 1) garden chrysanthemum would express significant increases in growth and leaf nutrient concentrations with increasing WSF rate when grown in a substratecontaining pecan wood chips, whereas such responses to WSF would be more limited in the absence of pecan wood, and 2) growth and leaf nutrient suppressions would increase

Received for publication 30 Sept. 2015. Accepted for publication 7 Dec. 2015.

This study was supported by the New Mexico Agricultural Experiment Station and by the Salopek Foundation.

We thank Sunland Nursery, Inc. and Aldershot of New Mexico for providing plant materials and greenhouse space for our pilot study in Fall 2012 completed by three students of our Greenhouse Management course: Nazar Al-Ibraheemi, Gerardo Toca, and Patrick Hernandez. For the present study of 2013, basal substrate compositional data and materials were provided by Aldershot of New Mexico, root samples were processed by Hae-Na Chung, shredded pecan wood and consultation were provided by Dickie Salopek and Brandon Stuart (Tom Salopek Farms), Lester Boyse expedited the wood collection, and Triston Hooks assisted with greenhouse irrigation. We also thank Richard Heerema and William Lindemann for reviewing the manuscript and for consultations.

${ }^{1}$ Graduate assistant

${ }^{2}$ Professor emeritus

${ }^{3}$ Corresponding author. E-mail: gpicchio@nmsu. edu. with increasing amounts of pecan wood in the substrate, especially at a low WSF rate.

Our objectives were to evaluate substrate electrical conductivity (EC) and $\mathrm{pH}$, vegetative growth, and leaf nutrient composition of garden chrysanthemum on a commercial peat-based substrate amended with various amounts of pecan wood chips, and subjected to varying rates of WSF. Here, we provide preliminary information to guide in developing sustainable practices that could advance the implementation of pecan wood substrates in greenhouse pot culture.

\section{Materials and Methods}

Pecan wood collection and processing. Pecan wood was obtained from a commercial orchard located $\approx 10 \mathrm{~km}$ north of Las Cruces, NM, in Doña Ana County. The mature orchard was hedge pruned in Dec. 2011 and the branches were windrowed. After windrowing, the branches were shredded using a brush shredder (Pow'rTrak model WS910; Flory Industries, Salida, CA), and the shreds were cut with an orchard flail mower (Vrisimo Model LP2144; Valley Tool Manufacturing Inc., Hughson, CA). The wood was then a heterogeneous, elongated mixture of coarse branch bark and wood with individual pieces ranging in length from $\approx 5$ to $12 \mathrm{~cm}$ and a thickness of $\approx 2 \mathrm{~cm}$ or less.

A sufficient volume of pecan wood was allowed to stand on the orchard floor in full sun until 27 Apr. 2012, when it was raked and bagged in a dry condition and stored at the New Mexico State University Fabian Garcia Science Center (FGSC) in Las Cruces, NM, where the study was conducted. On 31 May, the wood was chipped by a five-horsepower garden chipper-shredder (MTD Yard Machines model 245-645B; MTD Products, LLC, Cleveland, OH). The chipping procedure produced a mixture of elongated particles from $\approx 2$ to $5 \mathrm{~cm}$ long and $\approx 0.2$ to $0.3 \mathrm{~cm}$ wide, resembling wooden match sticks with finer chips intermingled. The chipped wood was passed through a $3.2-\mathrm{mm}$ screen to recover the finer material that was bagged and stored for $\approx 12$ months until use in the June 2013 study. The dominant size of the latter, elongated final chip preparation was around $1 \mathrm{~cm}$ long and $0.1 \mathrm{~cm}$ wide resembling a narrow version of rice hulls.

Pecan wood substrate preparation. The substrates were prepared 13 June 2013 at the FGSC using a local commercial grower's peat-based formulation that contained $67 \%$ peatmoss, $21 \%$ rice hulls, and $12 \%$ rockwool by volume. Wood chip mixing rates are defined as the amount (by volume) of peatmoss substitution in the grower's substrate: $0 \%$ (control, i.e., nonwood treatment), $25 \%$, $50 \%, 75 \%$, and $100 \%$. Volumetric proportions of wood were, respectively, $0 \%, 17 \%$, $33 \%, 50 \%$, and $67 \%$, with reciprocating proportions of peatmoss and constant proportions of rice hulls and rockwool to complete all physical components. All substrates were thoroughly mixed before use. To a $1 \mathrm{~m}^{3}$ equivalent of each of the premixed substrates, the following components were added and mixed thoroughly: $0.6 \mathrm{~kg}$ Talstar granular insecticide (FMC Professional Solutions, Philadelphia, PA), $1.7 \mathrm{~kg}$ calcitic limestone, $1.1 \mathrm{~kg}$ dolomitic limestone, and $0.3 \mathrm{~kg}$ each of $\mathrm{KNO}_{3}, \mathrm{FeSO}_{4}$, and Micromax Micronutrients (Everris NA, Inc.). Substrate preparation volumes were downscaled from $1 \mathrm{~m}^{3}$ for experimental purposes, as described in Picchioni et al. (2014).

Plant culture and greenhouse conditions. Two-liter pots were filled with the substrates on 13 June in a greenhouse at the FGSC. Tap water served as the only irrigation source and contained (in meq. $\mathrm{L}^{-1}$ ) $\mathrm{Na}(2.8), \mathrm{Ca}$ (2.4), $\mathrm{Mg}(1.0), \mathrm{K}(0.1), \mathrm{SO}_{4}$ (4.0), $\mathrm{Cl}(0.5)$, and $\mathrm{HCO}_{3}(1.8)$. The tap water also contained $\mathrm{P}$ at $1.2 \mathrm{mg} \cdot \mathrm{L}^{-1}$ but no detectable $\mathrm{NO}_{3}$ or $\mathrm{NH}_{4}$, and its $\mathrm{EC}$ and $\mathrm{pH}$ were $0.6 \mathrm{dS} \cdot \mathrm{m}^{-1}$ and 7.9 , respectively. Three WSF rates, supplied by 20N-9P-17K general purpose fertilizer (Scotts Co., Marysville, $\mathrm{OH}$ ) lacking $\mathrm{Ca}$, $\mathrm{Mg}$, and $\mathrm{SO}_{4}$, but containing all trace elements except $\mathrm{Ni}$ and $\mathrm{Cl}$, included $\mathrm{N}$ (in $\mathrm{mg} \cdot \mathrm{L}^{-1}$ of tap water) at $0\left(0.6 \mathrm{dS} \cdot \mathrm{m}^{-1}\right), 200\left(1.4 \mathrm{dS} \cdot \mathrm{m}^{-1}\right)$, and $400\left(2.2 \mathrm{dS} \cdot \mathrm{m}^{-1}\right)$, hereafter referred to as $0-\mathrm{N}$, $200-\mathrm{N}$, and $400-\mathrm{N}$, respectively. The pots were laid out as a split plot in a randomized complete block design with three blocks. Each block was comprised of a single pot for a given wood substitution $\times$ WSF treatment combination (further statistical details are forthcoming).

Rooted plants of 'Carpino' garden chrysanthemum (liner size 102) were obtained from Zylstra Growers (Kalamazoo, MI) on 18 June, moved to the greenhouse, irrigated with tap water as needed, and planted on 20 June at the rate of three plants per pot. Pots were immediately irrigated with tap water ( $800 \mathrm{~mL} /$ pot), and after 15 -min drainage, the initial container capacity weights were recorded. Initial shoot height at planting ranged from 5 to $7 \mathrm{~cm}$. Initial dry weights of roots and shoots (leaves plus stems) from five 3-plant samples were determined after drying to constant weight at $60{ }^{\circ} \mathrm{C}$ in a forced-draft oven (Model 1370D, Sheldon Manufacturing Inc., Cornelius, OR). Before weighing the roots, the original liner substrate was gently broken apart and the roots carefully isolated. Initial root dry weight was $0.28 \pm 0.01 \mathrm{~g}$ per three plants and initial shoot dry weight was $0.60 \pm 0.05 \mathrm{~g}$ per three plants. Plants were never pinched during the study.

During the 60-d greenhouse growth period (20 June to 19 Aug.), climate data were collected and analyzed using a Watchdog 2475 Plant Growth Weather Station and SpecWare 9 Basic software (Spectrum Technologies Inc., Aurora, IL). Maximum day temperature averaged $34{ }^{\circ} \mathrm{C}$ and minimum night temperature averaged $21^{\circ} \mathrm{C}$. Daily relative humidity averaged $53 \%$. Maximum photosynthetically active radiation was $706 \mu \mathrm{mol} \cdot \mathrm{m}^{-2} \cdot \mathrm{s}^{-1}$ and the daily light integral averaged $11 \mathrm{~mol} \cdot \mathrm{m}^{-2} \cdot \mathrm{d}^{-1}$. Photoperiod was held constant at $16 \mathrm{~h}$ with natural daylength and daylength extension lighting from 5 to $9 \mathrm{AM}$ and from 5 to $9 \mathrm{PM}$ provided by metal halide lamps.

Overhead irrigation began on 25 June with WSF applied at each irrigation using cups 
calibrated to known volumes. To avoid osmotic stress, the initial fertigation for the $400-\mathrm{N}$ treatment was applied at the rate of 200-N and then at $400-\mathrm{N}$ for all subsequent fertigations. Plants were fertigated when the pooled, three-pot wood percentage $\times$ WSF treatment weights (recorded daily) declined to a value that represented $50 \%$ of the total substrate moisture depletion, and in an amount to cause a targeted leaching fraction of $10 \%$. At planting, we found no differences in container capacity weights between the five wood substitution treatments, but the weights were reevaluated during the experiment and when increases were detected due to plant fresh biomass accumulation, adjustments to the fertigation timing and volumes were applied.

Leachate was pooled from the three pots per treatment, the volume measured, and the EC and $\mathrm{pH}$ were determined using a Myron Ultrameter (model 6P; Myron L. Co., Carlsbad, CA). Leachate collection dates were at the approximate midway and ending points of fertigation (22-25 July and 14-16 Aug., respectively). The EC and $\mathrm{pH}$ averages of the two measurements are reported in the text, as is a representative leaching fraction midway through the study. Starting the day after planting, ET was recorded as the daily change in weight per three-pot treatment. The total cumulative ET per three pots up to termination was then statistically assessed as described below.

Plant harvest, processing, and assessments. The experiment was ended on 19 Aug., which was $60 \mathrm{~d}$ after transplanting and $55 \mathrm{~d}$ after start of fertigation. Crop height was measured from the pot substrate line to the tallest leaf. Leaves, stems, and roots were then separated, washed three times in deionized water, and blotted dry. The total leaf area per pot was determined using a LI-3100C area meter (LI-COR Biosciences, Lincoln, NE). The total number of leaves per pot was counted and the average area per leaf calculated. Leaf, stem, and root tissues were dried to a constant weight at $60^{\circ} \mathrm{C}$ in the forced-draft oven previously described, and weighed. Roots were first isolated from the liner substrate as previously described.

The dried leaves were ground in a Wiley mill to pass a 40-mesh screen, and total $\mathrm{N}$ was determined in $100 \mathrm{mg}$ subsamples by combustion in a C-N furnace (Leco TruSpec CN; Leco Corp., St. Joseph, MI) following the methods of Horneck and Miller (1998). In $500 \mathrm{mg}$ subsamples, leaf $\mathrm{P}, \mathrm{K}, \mathrm{Ca}, \mathrm{Mg}, \mathrm{S}, \mathrm{Fe}$, $\mathrm{Mn}, \mathrm{B}, \mathrm{Cu}$, and $\mathrm{Zn}$ were extracted in nitric and perchloric acid, and determinations were made using an inductively coupled plasma emission spectrometer (Optima 7300DV; Perkin Elmer, Inc., Waltham, MA) using the methods in Miller (1998).

A subsample of the pecan wood chips was ground in the Wiley mill, from which a $5 \mathrm{mg}$ subsample was analyzed for $\mathrm{N}$ and $\mathrm{C}$ by combustion in a CHNS/O elemental analyzer (2400 Series II; Perkin Elmer, Inc.) by the methods in Wang et al. (2015). The C:N ratio was then determined. In addition, $\mathrm{P}$ and $\mathrm{K}$ concentrations in a $500 \mathrm{mg}$ subsample of the ground wood were determined as previously described for leaves.
Experimental design and statistical analysis. Cumulative ET per three pots at Day 59 was statistically assessed as nonreplicated data using a response surface and mean shift method (Cook and Weisberg, 1982). Data were analyzed by developing a regression model with linear WSF rate $(0-\mathrm{N}, 200-\mathrm{N}$, and $400-\mathrm{N}$, coded, respectively, as 0,2 , and 4 for the model fitting), linear wood substitution percentages $(0,25,50,75$, and 100), the linear WSF X wood substitution interaction, and a mean shift parameter (Cook and Weisberg, 1982) fitted for WSF at $200-\mathrm{N}$ and wood substitution at $0 \%$. This model allowed testing the hypothesis that for $0 \%$ wood substitution, growth (as inferred as ET) would be as much at $200-\mathrm{N}$ as at $400-\mathrm{N}$, thus making the 200-N treatment an exception to continuous, "stepwise" increases in ET with increasing WSF rate for plants receiving wood at $25 \%$ to $100 \%$ (i.e., incremental increase in ET between $200-\mathrm{N}$ and $400-\mathrm{N})$. The mean shift parameter was intuitively based on wood substrate studies on chrysanthemum by Wright et al. (2008) and Still et al. (1972), and our preliminary graphical assessment did, in fact, identify the $200-\mathrm{N}$ and $0 \%$ wood mean (high ET) as the only outlying data point among all of the other treatment means. The ET data were analyzed using SAS version 9.3 software (SAS Institute, Cary, NC), and significance within wood substitution rates was determined using $t$ tests to compare fitted values at $P \leq 0.05$.

Harvest data were subjected to analysis of variance (ANOVA) for a split plot with WSF rate as main plot and wood substitution level as subplot. The WSF rate was randomized within each of three blocks, and wood percentage was randomly assigned to subplots (single pots) within main plots. The ANOVA for crop height, average area per leaf, root: shoot dry weight ratio, leaf mineral concentrations, and the total leaf number, leaf area, leaf dry weight, stem dry weight, and root dry weight per pot was performed using the SAS PROC MIXED software version 9.3 (SAS Institute). Orthogonal polynomial contrasts were used to assess trends in WSF rate within wood substitution percentage and trends in wood substitution percentage within WSF rate.

\section{Results and Discussion}

Pot leaching characteristics. The target leaching fraction was $10 \%$ but the actual leaching fraction exceeded the target with increasing wood proportions. Midway through the study (22-25 July), the leaching fractions in the $0 \%, 25 \%, 50 \%, 75 \%$, and $100 \%$ wood substitution treatments ranged, respectively, as follows depending on the WSF rate: $9 \%$ to $13 \%, 17 \%$ to $23 \%, 24 \%$ to $28 \%, 32 \%$ to $39 \%$, and $38 \%$ to $47 \%$. Previous studies implicate higher air space and lower water holding capacity that lead to higher leaching in wood relative to nonwood substrates (Jackson et al., 2008; Wright et al., 2006, 2008).

In our conditions with soilless substrates, leachate $\mathrm{pH}$ and $\mathrm{EC}$ vary by less than $5 \%$, thus leachate data provide a close approximation of pour-through analyses. The recommended pour-through leachate $\mathrm{pH}$ and $\mathrm{EC}$ ranges for greenhouse chrysanthemum production are 5.7-6.2 and 2.6-4.6 dS. $\mathrm{m}^{-1}$, respectively (Cavins et al., 2000). As expected for the $0-\mathrm{N}$ treatment and depending on the wood substitution percentage, average leachate EC was unacceptably low $\left(0.8-1.2 \mathrm{dS} \cdot \mathrm{m}^{-1}\right)$ and average leachate $\mathrm{pH}$ was unacceptably high (7.1-7.4). At 200-N, the average leachate EC and $\mathrm{pH}$ for the $0 \%$ wood substitution treatment were within acceptable ranges $\left(3.1 \mathrm{dS} \cdot \mathrm{m}^{-1}\right.$ and 5.7 , respectively), whereas for the $25 \%$ to $100 \%$ wood substitution treatments, average leachate EC was below the accepted range $\left(1.5-1.6 \mathrm{dS} \cdot \mathrm{m}^{-1}\right)$ and average $\mathrm{pH}$ above the accepted range (6.9-7.1). At 400-N, each of the $0 \%, 25 \%$, and $50 \%$ wood substitution treatments provided an average leachate EC in the accepted range $\left(4.5,3.4\right.$, and $3.0 \mathrm{dS} \cdot \mathrm{m}^{-1}$, respectively), whereas the average leachate $\mathrm{EC}$ in the $75 \%$ and $100 \%$ wood substitution treatments was below the accepted range $\left(2.3-2.5 \mathrm{dS} \cdot \mathrm{m}^{-1}\right)$. The average leachate $\mathrm{pH}$ in the $400-\mathrm{N}$ treatment was within range for $0 \%$ wood substitution (6.1), only slightly above range for $25 \%$ wood (6.4), and increasingly above range for $50 \%$ to $100 \%$ wood (6.6-6.8).

The $\mathrm{N}$ composition of the WSF used in our study is dominated by $\mathrm{NH}_{4}$ and urea, which produce an acidifying effect in substrate solutions (Fisher et al., 2014). At $200-\mathrm{N}$, the acidifying effect was considerably reduced by any addition of pecan wood, and at $400-\mathrm{N}$, the acidifying effect was reduced by relatively high wood substitution levels of $50 \%$ to $100 \%$. Jackson et al. (2008, 2009) reported increases in pine-amended substrate $\mathrm{pH}$ at given fertilizer rates and concluded that those substrates are more weakly buffered against $\mathrm{pH}$ change than peat-based substrates. This also seems to apply to pecan wood substrates. Also, any addition of pecan wood strongly limited the nutrient supplying capability of the 200-N WSF treatment as inferred by leachate EC, although WSF at $400-\mathrm{N}$ counteracted that effect at wood substitution levels of $25 \%$ to $50 \%$ to allow adequate pot nutrition. These findings agree with those of Jackson et al. (2008) who concluded that higher fertilization rates are necessary to maintain wood-based substrate fertility and $\mathrm{pH}$ levels similar to those in a conventional nonwood substrate.

Cumulative crop ET. For cumulative ET per three pots at $59 \mathrm{~d}$, the linear regression model fit the data well $\left(R^{2}=0.988 ; \mathrm{F}_{4,10}=\right.$ $214.5, P<0.0001$ ). The fitted model (with SE of parameter estimates in parentheses) was cumulative $\mathrm{ET}=\left[\begin{array}{ll}11.1087 & (0.4350)\end{array}\right]-$ $[0.0319(0.0070)$ Wood \% $]+[2.7905$ (0.1607) WSF-N] $-[0.0164(0.0026)$ wood $\% \times$ WSF-N] $+[4.5003(0.6559)$ mean shift for $200-\mathrm{N}$ and $0 \%$ wood]. Estimated model parameters indicated that with pecan wood substitution, cumulative ET increased with WSF rate but the increase depended on the wood substitution level. Without wood chips, once adequate WSF was provided at either $200-\mathrm{N}$ or $400-\mathrm{N}$, the ET did not differ at around 21 to $22 \mathrm{~kg}$ per three pots, but did differ from the $0-\mathrm{N}$ mean of $\approx 11 \mathrm{~kg}$ per three pots (Table 1). At every other wood 
substitution level (25\% to $100 \%$ ), cumulative ET increased steadily from the $0-\mathrm{N}$ to the 400-N WSF levels, which resulted from similar incremental increases in total shoot biomass and leaf area to be discussed in the following section. Depending on wood substitution level, the total number of fertigation events ranged from 14 to $19(200-\mathrm{N})$ and from 18 to $20(400-\mathrm{N})$ with frequency generally decreasing with increasing wood percentage (data not shown).

The fitted model parameters indicate that for $25 \%$ wood substitution, a $100 \mathrm{mg} \cdot \mathrm{L}^{-1}$ unit increase in WSF-N ( 1 on analysis scale) produced a $2.38 \pm 0.11 \mathrm{~kg}$ increase in ET per three pots. However, at the $50 \%$ wood

Table 1. Model-based estimates at each sampling value on cumulative evapotranspiration at harvest (kilograms per three pots) for 'Carpino' garden chrysanthemum subjected to five pecan wood chip substitution rates and three water soluble fertilizer (WSF) rates expressed as nitrogen $(\mathrm{N})$ concentration. ${ }^{\mathrm{z}}$

\begin{tabular}{cccrrr}
\hline WSF-N & \multicolumn{5}{c}{ Wood substitution level (\%) } \\
\cline { 2 - 6 }$\left(\mathrm{mg} \cdot \mathrm{L}^{-1}\right)$ & 0 & 25 & 50 & 75 & 100 \\
\hline 0 & $11.1 \mathrm{~b}^{\mathrm{y}}$ & $10.3 \mathrm{c}$ & $9.5 \mathrm{c}$ & $8.7 \mathrm{c}$ & $7.9 \mathrm{c}$ \\
200 & $21.2 \mathrm{a}$ & $15.1 \mathrm{~b}$ & $13.5 \mathrm{~b}$ & $11.8 \mathrm{~b}$ & $10.2 \mathrm{~b}$ \\
400 & $22.3 \mathrm{a}$ & $19.8 \mathrm{a}$ & $17.4 \mathrm{a}$ & $15.0 \mathrm{a}$ & $12.5 \mathrm{a}$ \\
\hline
\end{tabular}

${ }^{\mathrm{z}}$ All substrates contained $\left(\right.$ per $\left.\mathrm{m}^{3}\right) 0.6 \mathrm{~kg}$ Talstar granular insecticide, $1.7 \mathrm{~kg}$ calcitic limestone, $1.1 \mathrm{~kg}$ dolomitic limestone, and $0.3 \mathrm{~kg}$ each of $\mathrm{KNO}_{3}, \mathrm{FeSO}_{4}$, and Micromax Micronutrients. Each substrate also contained (by volume) 21\% rice hulls and $12 \%$ rockwool. Wood substitution levels are defined as the amount (by volume) of peatmoss substitution at $0 \%, 25 \%, 50 \%, 75 \%$, and $100 \%$. The pecan wood was obtained after shredding the branches, chipping the shreds, and passing the shreds through a $3.2-\mathrm{mm}$ screen to obtain a final, dominant particle size of $\approx 1 \mathrm{~cm}$ long and $0.1 \mathrm{~cm}$ wide.

${ }^{\mathrm{y}}$ Mean separation within columns by least significant difference at $P \leq 0.05$.

Table 2. Harvest crop height, total leaf number per pot, and total leaf area per pot of 'Carpino' garden chrysanthemum subjected to five pecan wood chip substitution rates and three water soluble fertilizer (WSF) rates expressed as nitrogen (N) concentration. Substrate details in Table 1.

\begin{tabular}{|c|c|c|c|c|c|c|c|}
\hline \multirow{2}{*}{$\begin{array}{l}\text { WSF-N } \\
\left(\mathrm{mg} \cdot \mathrm{L}^{-1}\right)\end{array}$} & \multicolumn{5}{|c|}{ Wood substitution level (\%) } & \multicolumn{2}{|c|}{ Significance $^{\mathrm{z}}$} \\
\hline & 0 & 25 & 50 & 75 & 100 & Linear & Quadratic \\
\hline \multicolumn{8}{|c|}{ Crop height (cm) } \\
\hline 0 & 11.7 & 6.8 & 6.5 & 6.6 & 6.5 & $<0.0001$ & $<0.0001$ \\
\hline 200 & 20.3 & 18.2 & 11.5 & 10.0 & 8.7 & $<0.0001$ & 0.0010 \\
\hline 400 & 20.8 & 20.1 & 18.3 & 16.6 & 15.0 & $<0.0001$ & 0.3629 \\
\hline \multicolumn{8}{|l|}{ Significance ${ }^{y}$} \\
\hline Linear & $<0.0001$ & $<0.0001$ & $<0.0001$ & $<0.0001$ & $<0.0001$ & - & - \\
\hline Quadratic & $<0.0001$ & $<0.0001$ & 0.1047 & 0.0065 & 0.0008 & - & - \\
\hline \multicolumn{8}{|c|}{ Leaves (number per pot) } \\
\hline 0 & 50.0 & 44.7 & 42.0 & 41.0 & 41.3 & 0.8161 & 0.9031 \\
\hline 200 & 468.3 & 186.0 & 74.0 & 68.3 & 57.3 & $<0.0001$ & $<0.0001$ \\
\hline 400 & 481.7 & 324.7 & 247.7 & 222.0 & 108.3 & $<0.0001$ & 0.2040 \\
\hline \multicolumn{8}{|l|}{ Significance } \\
\hline Linear & $<0.0001$ & $<0.0001$ & $<0.0001$ & $<0.0001$ & 0.0747 & - & - \\
\hline Quadratic & $<0.0001$ & 0.9662 & 0.0321 & 0.0537 & 0.5797 & - & - \\
\hline \multicolumn{8}{|c|}{ Leaf area $\left(\mathrm{cm}^{2} / p o t\right)$} \\
\hline 0 & 204.3 & 146.9 & 148.8 & 163.5 & 154.1 & 0.7250 & 0.6993 \\
\hline 200 & 2343.5 & 1217.8 & 450.6 & 328.4 & 241.9 & $<0.0001$ & $<0.0001$ \\
\hline 400 & 2190.0 & 1956.0 & 1615.3 & 1235.5 & 708.9 & $<0.0001$ & 0.0343 \\
\hline \multicolumn{8}{|l|}{ Significance } \\
\hline Linear & $<0.0001$ & $<0.0001$ & $<0.0001$ & $<0.0001$ & $<0.0001$ & - & - \\
\hline Quadratic & $<0.0001$ & 0.0539 & $<0.0001$ & $<0.0001$ & 0.0297 & - & - \\
\hline
\end{tabular}

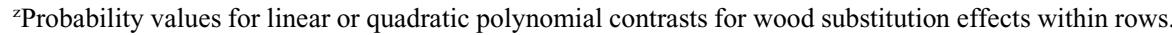

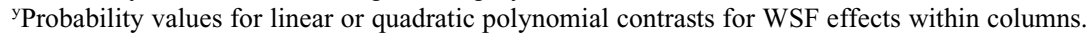

In the $0-\mathrm{N}$ treatment, any addition of wood reduced crop height to about one-half that of the $0 \%$ wood substitution level. Even with no WSF, plants grown in the nonwood control were as tall as or taller than with $200-\mathrm{N}$ and wood substitution at $50 \%$ to $100 \%$. With WSF at 200-N, quadratic responses to wood substitution percentage were associated with steep falloffs in height (50\% wood), and in leaf number and area (25\% and 50\% wood), with small drops at higher wood percentages. At $400-\mathrm{N}$, increasing the wood percentage resulted in significant linear declines in height, leaf number, and leaf area, but this high WSF rate minimized the suppressions at $25 \%$ or $50 \%$ wood that occurred at $200-\mathrm{N}$ (Table 2; Fig. 1). Leaf area declines with increasing wood resulted from leaf number reductions, since for average area per leaf (data not shown), neither the wood substitution main effect nor the wood substitution level $\times$ WSF interaction were significant ( $P=0.3020$ and 0.0798 , respectively). However, area per leaf did increase linearly with increasing WSF rate $(P=0.0033)$ with averages of $3.7,5.4$, and $6.0 \mathrm{~cm}^{2} /$ leaf for the $0-\mathrm{N}$, $200-\mathrm{N}$, and $400-\mathrm{N}$ rates, respectively.

The wood percentage $\times$ WSF interaction was also observed for total leaf and stem dry weights at harvest (Table 3). Namely, the quadratic WSF rate effect at $0 \%$ wood substitution was attributed to lack of leaf and stem weight responses at $400-\mathrm{N}$, whereas there were considerable increases in leaf and stem weights of wood-treated plants at $400-\mathrm{N}$, especially at $50 \%$ and $75 \%$ wood substitution. Throughout a WSF-N concentration range of 50 to $400 \mathrm{mg} \cdot \mathrm{L}^{-1}$, Wright et al. (2008) reported a linear increase in shoot dry weight of garden chrysanthemum in a $100 \%$ pine wood chip substrate compared with a curvilinear ("tailing off") shoot growth response in a peat-based substrate, similar to our findings on garden chrysanthemum with pecan wood chips. In addition, the interaction we observed between fertilizer rate and wood percentage on top growth was also observed by Jackson et al. (2008) for shoot growth of several woody crops. They reported greater shoot growth stimulation on a pine wood substrate than on a conventional pine bark substrate with increasing slow-release fertilizer rate.

Quadratic declines in leaf dry weight and stem dry weight occurred across wood substitution levels for plants receiving $200-\mathrm{N}$, with large reductions at $25 \%$ and $50 \%$ wood substitution and smaller reductions at higher wood substitution. By contrast, at 400-N, the quadratic effect of wood substitution on leaf dry weight occurred from the relatively small reductions for as much as $50 \%$ wood substitution. In addition, the declining linear trend for stem dry weight at $400-\mathrm{N}$ contrasted the steep quadratic stem weight decline at low wood percentages for its counterpart 200-N treatment just mentioned.

Another side of nutrient limitations is on the root response. With $25 \%$ and $50 \%$ wood substitution, harvested root dry weight was $61 \%$ to $91 \%$ higher at $200-\mathrm{N}$ than at $0-\mathrm{N}$, 

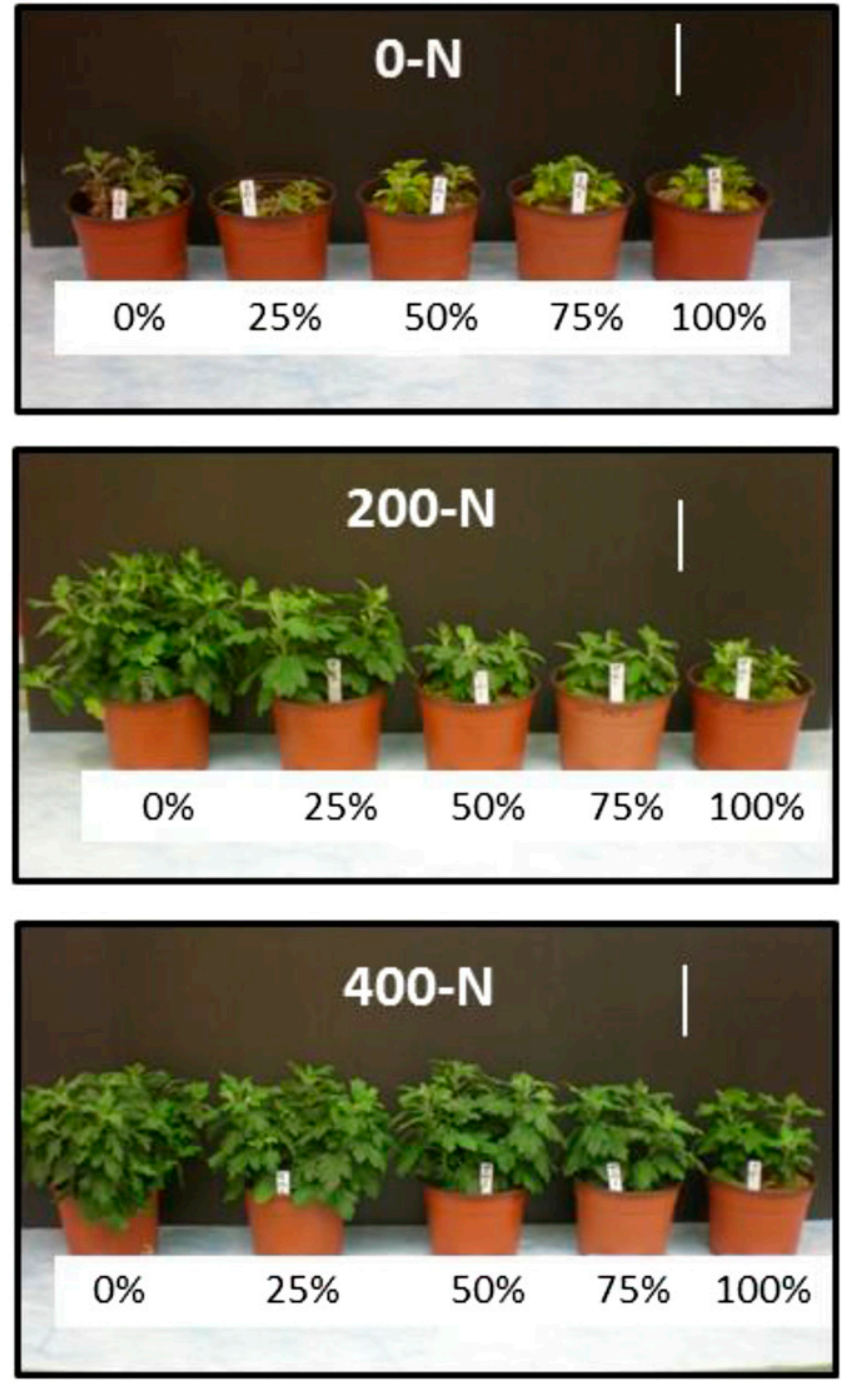

Fig. 1. The 60-d harvest appearance of 'Carpino' garden chrysanthemum subjected to five pecan wood chip substitution rates and three water soluble fertilizer (WSF) rates expressed as nitrogen (N) concentration in $\mathrm{mg} \cdot \mathrm{L}^{-1}$. One complete replication for each of the WSF rates of $0-\mathrm{N}, 200-\mathrm{N}$ and $400-\mathrm{N}$ appear from top to bottom, respectively. Wood substitution percentages shown below pots; vertical scale line $\approx 10$ $\mathrm{cm}$. Substrate details in Table 1.

with no additional increases at $400-\mathrm{N}$ (Table 3 ). At $200-\mathrm{N}$, a strongly positive quadratic effect of wood substitution on root weight occurred that was weaker at $400-\mathrm{N}$. Thus, chrysanthemum root weight increased significantly with as much as $50 \%$ pecan wood $(200-\mathrm{N})$ or $75 \%$ pecan wood $(400-\mathrm{N})$.

The root:shoot dry weight ratio at harvest was relatively high for all wood substitution levels receiving no WSF (Table 3). Different types of quadratic declines in root:shoot ratio with increasing WSF rate were observed, depending on the wood substitution percentage. For the $0 \%$ and $25 \%$ wood substitution levels, the major declines were at 200-N whereas with the higher wood substitution levels, the major declines were at 400-N. With WSF at 200-N, wood substitution had a quadratic effect on root:shoot ratio, which increased by $\approx 6$-fold at $50 \%$ wood and not much more with higher wood levels. With WSF at 400-N, root:shoot ratio increased linearly with increasing wood percentage, but not to such high values as at $200-\mathrm{N}$. This may indicate that high WSF at $400-\mathrm{N}$ partially circumvented an adaptive need for chrysanthemum to favor roots in dry matter partitioning.

Preferential dry matter allocation to roots is a signature trait of plants in nutrientlimiting conditions, and Wilson (1988) cited numerous reports showing an increase in root: shoot ratio of plants under nutrient deficiency, particularly of major nutrients. Under P-limiting conditions, for example, plants simply grow more roots (Schachtman et al., 1998). Increased root:shoot ratio noted previously raises the possibility that moderate amounts of pecan wood could improve outplanting survival of outdoor crops. Data on root developmental plasticity in wood-based substrates are limited, and are needed to further address this possibility.

Leaf nutrient concentrations. Within-column polynomial contrasts for leaf $\mathrm{N}$ concentration showed highly significant increasing quadratic trends that differed among the wood substitution levels (Table 4). For $0 \%$ and $25 \%$ wood substitution, $200-\mathrm{N}$ provided the largest increase in leaf $\mathrm{N}$ with comparatively small increments at 400-N. Conversely, the quadratic trends for leaf $\mathrm{N}$ at $50 \%$ to $100 \%$ wood substitution resulted from the large increases (2-fold or more) from $200-\mathrm{N}$ to $400-\mathrm{N}$. A descending quadratic response of leaf $\mathrm{N}$ to increasing wood substitution level at 200-N was observed, with the sharpest decline at $50 \%$ wood substitution and smaller declines at higher wood levels. At 400-N, a more gradual linear decline in leaf $\mathrm{N}$ across the wood substitution levels occurred.

A quadratic WSF effect on leaf $P$ concentration without wood chips was, once again, the result of a large increase from $0-\mathrm{N}$ to $200-\mathrm{N}$ and only a slight increase from $200-\mathrm{N}$ to $400-\mathrm{N}$ (Table 4). Leaf $\mathrm{P}$ in all of the woodsupplemented treatments increased linearly with WSF rate, although the size of the increase was progressively smaller with each increase in wood substitution level. Declining quadratic trends for leaf $\mathrm{P}$ in the $200-\mathrm{N}$ and 400-N WSF rates across the wood substitution levels differed. At $200-\mathrm{N}$, leaf $\mathrm{P}$ declined considerably at $25 \%$ and $50 \%$ wood substitution with smaller declines at $75 \%$ and $100 \%$ wood substitution. At $400-\mathrm{N}$, leaf $\mathrm{P}$ declined only with $50 \%$ to $100 \%$ wood substitution. Thus, for both leaf N and P, WSF at 400-N counteracted much of the effect of increasing wood proportions observed with WSF at $200-\mathrm{N}$.

Only main effects of wood substitution and WSF rate affected leaf $\mathrm{K}$ concentration $(P \leq 0.0246)$ with no interaction $(P=0.5931 ; \mathrm{K}$ data not presented). Leaf $\mathrm{K}$ decreased with increasing wood proportions of $0 \%$ to $100 \%$ $(3.9 \%, 3.0 \%, 3.0 \%, 2.9 \%$, and $2.9 \%$ of dry weight, respectively), and increased with increasing WSF rate of $0-\mathrm{N}$ to $400-\mathrm{N}(2.2 \%$, $3.5 \%$, and $3.7 \%$ of dry weight, respectively). Thus, increasing the WSF rate to $400-\mathrm{N}$ did not specifically boost leaf $\mathrm{K}$ status in woodsupplemented substrate. Increasing the rate of WSF (which lacked $\mathrm{Ca}$ and $\mathrm{Mg}$ ) did not increase leaf $\mathrm{Ca}$ and $\mathrm{Mg}$ concentrations within given wood substitution levels, and increasing wood proportions did not reduce leaf $\mathrm{Ca}$ and $\mathrm{Mg}$ concentrations within WSF rates (data not shown). At $200-\mathrm{N}$, a quadratic decline in leaf $\mathrm{S}$ concentration occurred $(P=0.0104)$, from $0.30 \%$ to $0.31 \%$ of dry weight with $0 \%$ and $25 \%$ wood substitution to $0.21 \%$ to $0.23 \%$ of dry weight with $50 \%$ to $100 \%$ wood substitution (data not shown). However, at $400-\mathrm{N}$, leaf S concentrations were $0.33 \%$ to $0.35 \%$ of dry weight and were independent of the wood substitution level. This may indicate that the increased top growth of plants receiving pecan wood and with WSF at 400-N (lacking $\mathrm{SO}_{4}$ ) increased $\mathrm{SO}_{4}$ demand and uptake from the tap water and preplant fertilizer.

Data in Table 5 suggest that increasing pecan wood substitution levels limited availability of $\mathrm{Fe}, \mathrm{Mn}, \mathrm{Cu}$, and $\mathrm{Zn}$. Any addition of wood prevented increases in leaf Fe concentration with increasing WSF rate that were observed without the addition of wood (Table 5). Quadratic reductions in leaf $\mathrm{Fe}$ within WSF rates of 200-N and 400-N resulted from large declines with $25 \%$ wood substitution $(200-\mathrm{N})$ and $25 \%$ to $50 \%$ wood substitution $(400-\mathrm{N})$, 
Table 3. Harvest leaf, stem, and root dry weight, and harvest root:shoot dry weight ratio of 'Carpino' garden chrysanthemum subjected to five pecan wood chip substitution rates and three water soluble fertilizer (WSF) rates expressed as nitrogen $(\mathrm{N})$ concentration. Substrate details in Table 1.

\begin{tabular}{|c|c|c|c|c|c|c|c|}
\hline \multirow[b]{2}{*}{ WSF-N $\left(\mathrm{mg} \cdot \mathrm{L}^{-1}\right)$} & \multicolumn{5}{|c|}{ Wood substitution level (\%) } & \multicolumn{2}{|c|}{ Significance $^{z}$} \\
\hline & 0 & 25 & 50 & 75 & 100 & Linear & $\overline{\text { Quadratic }}$ \\
\hline \multicolumn{8}{|c|}{ Leaf dry wt (g/pot) } \\
\hline 0 & 1.59 & 1.28 & 1.43 & 1.56 & 1.44 & 0.9816 & 0.7741 \\
\hline 200 & 11.00 & 6.26 & 2.83 & 2.20 & 1.77 & $<0.0001$ & $<0.0001$ \\
\hline 400 & 9.88 & 9.10 & 8.13 & 6.11 & 3.65 & $<0.0001$ & 0.0011 \\
\hline \multicolumn{8}{|l|}{ Significance $^{\mathrm{y}}$} \\
\hline Linear & $<0.0001$ & $<0.0001$ & $<0.0001$ & $<0.0001$ & $<0.0001$ & - & - \\
\hline Quadratic & $<0.0001$ & 0.0055 & $<0.0001$ & $<0.0001$ & 0.0374 & - & - \\
\hline \multicolumn{8}{|c|}{ Stem dry wt (g/pot) } \\
\hline 0 & 0.57 & 0.38 & 0.37 & 0.37 & 0.32 & 0.2212 & 0.5650 \\
\hline 200 & 4.10 & 1.38 & 0.64 & 0.51 & 0.45 & $<0.0001$ & $<0.0001$ \\
\hline 400 & 3.69 & 2.73 & 2.04 & 1.39 & 0.74 & $<0.0001$ & 0.1831 \\
\hline \multicolumn{8}{|l|}{ Significance } \\
\hline Linear & $<0.0001$ & $<0.0001$ & $<0.0001$ & $<0.0001$ & 0.0188 & - & - \\
\hline Quadratic & $<0.0001$ & 0.2360 & 0.0005 & 0.0159 & 0.5764 & - & - \\
\hline \multicolumn{8}{|c|}{ Root dry wt (g/pot) } \\
\hline 0 & 1.31 & 0.94 & 0.99 & 1.31 & 1.02 & 0.4624 & 0.2366 \\
\hline 200 & 1.36 & 1.51 & 1.89 & 1.57 & 1.35 & 0.9185 & 0.0003 \\
\hline 400 & 1.27 & 1.37 & 1.59 & 1.61 & 1.25 & 0.4624 & 0.0032 \\
\hline \multicolumn{8}{|l|}{ Significance } \\
\hline Linear & 0.8043 & 0.0269 & 0.0044 & 0.1012 & 0.1914 & - & - \\
\hline Quadratic & 0.6372 & 0.0321 & 0.0015 & 0.4786 & 0.1783 & - & - \\
\hline \multicolumn{8}{|c|}{ Root:shoot dry wt ratio } \\
\hline 0 & 0.61 & 0.56 & 0.55 & 0.67 & 0.59 & 0.5386 & 0.6492 \\
\hline 200 & 0.09 & 0.20 & 0.56 & 0.58 & 0.62 & $<0.0001$ & 0.0061 \\
\hline 400 & 0.09 & 0.12 & 0.16 & 0.22 & 0.29 & 0.0010 & 0.4597 \\
\hline \multicolumn{8}{|l|}{ Significance } \\
\hline Linear & $<0.0001$ & $<0.0001$ & $<0.0001$ & $<0.0001$ & 0.0002 & - & - \\
\hline Quadratic & 0.0002 & 0.0234 & 0.0017 & 0.0316 & 0.0048 & - & - \\
\hline
\end{tabular}

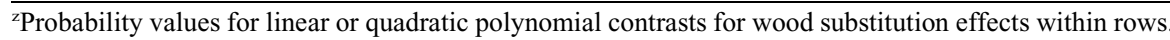
yProbability values for linear or quadratic polynomial contrasts for WSF effects within columns.

Table 4. Harvest leaf nitrogen $(\mathrm{N})$ and phosphorus $(\mathrm{P})$ concentrations of 'Carpino' garden chrysanthemum subjected to five pecan wood chip substitution rates and three water soluble fertilizer (WSF) rates expressed as N concentration. Substrate details in Table 1.

\begin{tabular}{|c|c|c|c|c|c|c|c|}
\hline \multirow[b]{2}{*}{ WSF-N $\left(\mathrm{mg} \cdot \mathrm{L}^{-1}\right)$} & \multicolumn{5}{|c|}{ Wood substitution level (\%) } & \multicolumn{2}{|c|}{ Significance $^{z}$} \\
\hline & 0 & 25 & 50 & 75 & 100 & Linear & $\overline{\text { Quadratic }}$ \\
\hline \multicolumn{8}{|c|}{ Leaf $N$ concn (\% of dry wt) } \\
\hline 0 & 1.40 & 0.94 & 0.86 & 0.92 & 0.92 & $<0.0001$ & $<0.0001$ \\
\hline 200 & 4.91 & 4.49 & 2.72 & 2.14 & 1.83 & $<0.0001$ & $<0.0001$ \\
\hline 400 & 6.10 & 5.66 & 5.40 & 5.00 & 4.45 & $<0.0001$ & 0.1024 \\
\hline \multicolumn{8}{|l|}{ Significance ${ }^{y}$} \\
\hline Linear & $<0.0001$ & $<0.0001$ & $<0.0001$ & $<0.0001$ & $<0.0001$ & - & - \\
\hline Quadratic & $<0.0001$ & $<0.0001$ & $<0.0001$ & $<0.0001$ & $<0.0001$ & - & - \\
\hline \multicolumn{8}{|c|}{ Leaf P concn ( $\%$ of dry wt) } \\
\hline 0 & 0.48 & 0.27 & 0.18 & 0.17 & 0.16 & $<0.0001$ & $<0.0001$ \\
\hline 200 & 1.25 & 0.91 & 0.66 & 0.53 & 0.45 & $<0.0001$ & $<0.0001$ \\
\hline 400 & 1.36 & 1.43 & 1.12 & 0.93 & 0.75 & $<0.0001$ & $<0.0001$ \\
\hline \multicolumn{8}{|l|}{ Significance } \\
\hline Linear & $<0.0001$ & $<0.0001$ & $<0.0001$ & $<0.0001$ & $<0.0001$ & - & - \\
\hline Quadratic & $<0.0001$ & 0.1750 & 0.8818 & 0.5766 & 0.8408 & - & - \\
\hline
\end{tabular}

zProbability values for linear or quadratic polynomial contrasts for wood substitution effects within rows. yProbability values for linear or quadratic polynomial contrasts for WSF effects within columns.

with relatively little change at higher wood proportions.

Leaf Mn concentrations were highest in the $0 \%$ wood substitution level even with no WSF (Table 5). At 200-N, wood substitution had a quadratic effect in that low or high wood percentages reduced leaf $\mathrm{Mn}$ concentration by $\approx 3$ - to 4 -fold. With wood substitution at $25 \%$ and $50 \%$, high WSF $(400-\mathrm{N})$ partially counteracted the steep declines in leaf Mn observed at $200-\mathrm{N}$, unlike the leaf $\mathrm{Fe}$ response.

For all wood substitution levels except $100 \%$, leaf $\mathrm{Cu}$ concentration increased linearly with increasing WSF rate (Table 5). Wood with relatively little indication that the high WSF rate of 400-N counteracted the declines at lower WSF of 200-N, unlike leaf $\mathrm{Mn}$ and $\mathrm{Cu}$. Leaf B concentration (data not shown) ranged from 43 to $85 \mathrm{mg} \cdot \mathrm{kg}^{-1}$ dry weight and was unaffected by wood substitution level $(P=$ $0.0617), \mathrm{WSF}$ rate $(P=0.5825)$, or the wood substitution $\times \mathrm{WSF}$ interaction $(P=0.2798)$.

According to collective leaf nutrient diagnostic criteria for chrysanthemum in Dole and Wilkins (2005) and Nelson (2012), most of the leaf $\mathrm{N}$ and $\mathrm{P}$ concentrations at $0-\mathrm{N}$ (Table 4) were at deficient levels as expected, although among the trace metals (Table 5), only leaf $\mathrm{Cu}$ at $0-\mathrm{N}$ with $50 \%$ or $75 \%$ pecan wood substitution would be considered as inadequate. At $200-\mathrm{N}$, leaf $\mathrm{N}$ with $50 \%$ to $100 \%$ wood substitution was insufficient. Leaf $\mathrm{K}$ was deficient with any addition of wood. The generalized criteria do not account for unknown cultivar-specific responses to leaf nutrient concentrations (Paparozzi, 2003). With high WSF at $400-\mathrm{N}$, increasing wood proportions reduced leaf $\mathrm{N}, \mathrm{P}$, and trace metal concentrations although not to insufficient levels according to the general criteria. This leaves unanswered the question as to whether those minerals were deficient for this cultivar.

\section{Biological and horticultural implications for a pecan wood "eco-cycle"}

When shredded pecan branches are recycled to the orchard floor, they complete a closed wood eco-cycle that, in New Mexico, may be the most reasonable disposal option at this time. Based on our findings, greenhouse crops have potential to become part of the cycle and provide a value-added option for pecan growers, which has proven successful in southern pine forests and plantations. To meet the potential, refinements in pecan wood processing and greenhouse cultural practices are needed.

The $0-\mathrm{N}$ WSF rate provided little value for assessing plant response to substrate on realistic horticulture terms, but it provided additional evidence for nutrient-limiting conditions using pecan wood chips. With $0-\mathrm{N}$, declines in crop height and in leaf N, P, Mn, $\mathrm{Cu}$, and $\mathrm{Zn}$ across the wood substitution levels demonstrate the potential for wood-related deficits in nutrient availability, in this case for $\mathrm{N}$ and trace metals in the preplant fertilizer and for low $\mathrm{P}\left(1.2 \mathrm{mg} \cdot \mathrm{L}^{-1}\right)$ in the tap water.

Low fertility in pine wood substrates is thought to result from 1) increased air space leading to reduced water and nutrient retention and, thus, increased leaching losses, 2) immobilization of nutrients by microorganisms, or 3) both (Gaches et al., 2011; Jackson et al., 2008; Wright et al., 2006, 2008). Whatever the case, pecan wood substitution reduced substrate fertility in our study. Still another possibility for growth suppression in pecan substrate is an allelopathic effect of the wood. Juglone, an allelopathic compound, is present in pecan twigs, twig bark, and trunks (Borazjani et al., 1985). Our wood was dry and presumably free of chemical toxins that may exist in fresh wood chips of other tree species (Gaches et al., 2011; Still et al., 1972). In substrates containing pecan wood chips, the significant responses 
Table 5. Harvest leaf iron ( $\mathrm{Fe})$, manganese $(\mathrm{Mn})$, copper $(\mathrm{Cu})$, and zinc $(\mathrm{Zn})$ concentrations of 'Carpino' garden chrysanthemum subjected to five pecan wood chip substitution rates and three water soluble fertilizer (WSF) rates expressed as nitrogen $(\mathrm{N})$ concentration. Substrate details in Table 1.

\begin{tabular}{|c|c|c|c|c|c|c|c|}
\hline \multirow[b]{2}{*}{ WSF-N $\left(\mathrm{mg} \cdot \mathrm{L}^{-1}\right)$} & \multicolumn{5}{|c|}{ Wood substitution level (\%) } & \multicolumn{2}{|c|}{ Significance $^{z}$} \\
\hline & 0 & 25 & 50 & 75 & 100 & Linear & Quadratic \\
\hline \multicolumn{8}{|c|}{ Leaf Fe conch $\left(\mathrm{mg} \cdot \mathrm{kg}^{-1}\right.$ dry $\left.\mathrm{wt}\right)$} \\
\hline 0 & 88.5 & 95.9 & 77.6 & 80.9 & 83.2 & 0.2219 & 0.6340 \\
\hline 200 & 112.0 & 91.7 & 89.3 & 80.0 & 98.0 & 0.0619 & 0.0078 \\
\hline 400 & 158.9 & 123.6 & 98.8 & 99.9 & 104.8 & $<0.0001$ & 0.0002 \\
\hline \multicolumn{8}{|l|}{ Significance $^{\mathrm{y}}$} \\
\hline Linear & 0.0001 & 0.0881 & 0.1757 & 0.2198 & 0.1705 & - & - \\
\hline Quadratic & 0.3746 & 0.1830 & 0.9334 & 0.4269 & 0.7599 & - & - \\
\hline \multicolumn{8}{|c|}{ Leaf Mn concn $\left(m g \cdot \mathrm{kg}^{-1}\right.$ dry wt) } \\
\hline 0 & 257.6 & 88.9 & 81.9 & 80.9 & 88.8 & $<0.0001$ & $<0.0001$ \\
\hline 200 & 338.6 & 84.4 & 87.8 & 98.5 & 102.8 & $<0.0001$ & $<0.0001$ \\
\hline 400 & 271.7 & 190.2 & 127.1 & 97.4 & 103.5 & $<0.0001$ & $<0.0001$ \\
\hline \multicolumn{8}{|l|}{ Significance } \\
\hline Linear & 0.3256 & $<0.0001$ & 0.0059 & 0.2536 & 0.3050 & - & - \\
\hline Quadratic & $<0.0001$ & 0.0005 & 0.1868 & 0.4490 & 0.5898 & - & - \\
\hline \multicolumn{8}{|c|}{ Leaf Cu concn $\left(m g \cdot \mathrm{kg}^{-1} d r y w t\right)$} \\
\hline 0 & 12.23 & 7.34 & 6.19 & 6.28 & 7.90 & 0.0012 & 0.0001 \\
\hline 200 & 16.75 & 12.66 & 8.94 & 10.19 & 8.11 & $<0.0001$ & 0.0085 \\
\hline 400 & 18.43 & 16.41 & 14.62 & 14.25 & 9.59 & $<0.0001$ & 0.2321 \\
\hline \multicolumn{8}{|l|}{ Significance } \\
\hline Linear & $<0.0001$ & $<0.0001$ & $<0.0001$ & $<0.0001$ & 0.1619 & - & - \\
\hline Quadratic & 0.1765 & 0.4492 & 0.1645 & 0.9409 & 0.5412 & - & - \\
\hline \multicolumn{8}{|c|}{ Leaf Zn concn $\left(m g \cdot k g^{-1} d r v w t\right)$} \\
\hline 0 & 58.0 & 37.8 & 29.6 & 31.6 & 34.6 & 0.0006 & 0.0015 \\
\hline 200 & 96.8 & 84.6 & 72.6 & 61.6 & 58.6 & $<0.0001$ & 0.2327 \\
\hline 400 & 103.1 & 103.8 & 79.0 & 78.5 & 61.1 & $<0.0001$ & 0.4594 \\
\hline \multicolumn{8}{|l|}{ Significance } \\
\hline Linear & $<0.0001$ & $<0.0001$ & $<0.0001$ & $<0.0001$ & $<0.0001$ & - & - \\
\hline Quadratic & 0.0021 & 0.0075 & 0.0007 & 0.1776 & 0.0326 & - & - \\
\hline
\end{tabular}

${ }^{2}$ Probability values for linear or quadratic polynomial contrasts for wood substitution effects within rows. 'Probability values for linear or quadratic polynomial contrasts for WSF effects within columns.

of top growth and of leaf $\mathrm{N}, \mathrm{P}, \mathrm{Mn}, \mathrm{Cu}$, and $\mathrm{Zn}$ to high WSF at $400-\mathrm{N}$, and of root growth with WSF at 200-N or 400-N, suggest that substrate fertility was the main growth-limiting factor.

Our study supports both of the theories 1 and 2 above. Firstly, the target leaching fraction of $10 \%$ became progressively higher with each increase in wood substitution, which backs the nutrient leaching loss explanation. Secondly, at harvest time of only the wood-supplemented pots, we observed white mycelia and fruiting bodies of an unidentified Pleurotus sp., which is a white rot fungal taxon known to colonize pecan (U.S. Forest Service, 2015), and thus a component of the orchard eco-cycle. No attempts were made to quantify the fungal growth and visual observation showed no apparent relationship between its growth and WSF rate. Mycelia were found inside and throughout the surfaces of the root ball and were most abundant in the $50 \%$ to $100 \%$ wood substitution substrates (example in Fig. 2A). Fruiting bodies were observed even at the low wood substitution level of $25 \%$ (Fig. 2B) although they, too, increased with the wood substitution level. Mycelia-occupied substrate was dry to the touch, probably because of their hydrophobic properties that affect water:soil relationships (Ritz and Young, 2004). Thus, one nutrientlimiting factor (microbial activity) may exacerbate the impact of the other nutrient-limiting factor (water and nutrient retention), merely adding to the complexity of the basis for low fertility.

Among the essential nutrients for fungi are $\mathrm{N}, \mathrm{P}, \mathrm{K}, \mathrm{Fe}, \mathrm{Mn}, \mathrm{Cu}$, and $\mathrm{Zn}$ (Griffin,
1994). Each of these nutrients declined in leaves of chrysanthemum growing in our substrates containing pecan wood. Thus, the prevailing wood-related microbial $\mathrm{N}$ immobilization hypothesis (Boyer et al., 2012a, 2012b; Fain et al., 2008; Gaches et al., 2011; Jackson et al., 2008, 2009; Witcher et al., 2014; Wright et al., 2006, 2008) discounts the potential for microbial immobilization of other plant nutrients.

The pecan wood chips in our study had a $\mathrm{C}: \mathrm{N}$ mass ratio of 94 . From the soil tillage study by Tahboub et al. (2007), pecan wood chips from an orchard in nearby semiarid west Texas had a $\mathrm{C}: \mathrm{N}$ ratio of 143 . A $0.15 \%$ difference in wood $\mathrm{N}(0.49 \%$ and $0.34 \%$ of dry weight in the present study vs. their study, respectively) led to the large difference in $\mathrm{C}: \mathrm{N}$ ratio. Variation in $\mathrm{C}: \mathrm{N}$ ratio might warrant adjustments to $\mathrm{N}$ fertilization rates for greenhouse substrates amended with pecan wood. Regional standardization of pecan hedge pruning and soil management practices could minimize source-tosource variation in pecan wood nutrient content and thereby simplify potting substrate management. For example, regular hedge pruning, as compared with infrequent pruning, would presumably provide higher wood N concentrations. Also, the "on" year of the pecan alternate bearing cycle depletes wood storage reserves that include $\mathrm{N}$ (Grauke and Thompson, 1996), and regular hedge pruning can mitigate the cycle (Wood and Stahmann, 2004). Furthermore, pecan leaf $\mathrm{N}$ and $\mathrm{P}$ remobilization before autumn leaf drop, and thus $\mathrm{N}$ and $\mathrm{P}$ wood storage reserves, may be reduced under even moderately low saline conditions, an important consideration for salt-sensitive pecan in the semiarid United States (Picchioni et al., 2000b). A broader picture to emerge is that for nutrients besides $\mathrm{N}$, since the mass ratios of $\mathrm{C}: \mathrm{P}$ and of $\mathrm{C}: \mathrm{K}$ in the wood chips used in our study ( 270 and 1528 , respectively) were 3 to 16 times higher than for $\mathrm{C}: \mathrm{N}$. Therefore, microbial demands for $\mathrm{P}$ and $\mathrm{K}$ in pecan wood substrates may be limiting factors in addition to $\mathrm{N}$.

Findings from the present study exposed the main elements of concern from previously cited wood chip substrate studies, which included high leaching fractions, reductions in substrate fertility, increases in substrate $\mathrm{pH}$, and reductions in shoot growth and leaf nutrient levels. High WSF at 400-N proved necessary with even the smallest substitution of pecan wood chips $(25 \%)$ to achieve comparable growth as a conventional system with only peatmoss and 200-N. A WSF rate of 400-N was also used in the chrysanthemum studies by Still et al. (1972) with oak sawdust, and Wright et al. (2008) with pine wood chips for growth results that were comparable to their conventional peatonly, lower $\mathrm{N}$ culture systems. Their wood volumetric proportions were $33 \%$ to $100 \%$, indicating that there may be added limitations on use of pecan wood chips over other wood chip sources to grow chrysanthemum.

High WSF rates such as 400-N along with increased leaching fractions, as applicable to our study, may not be economically and environmentally sustainable (Biernbaum, 1992). Research on physical properties of pecan wood chips is needed to integrate lower WSF rates with lower irrigation volumes to reduce leaching fractions, retain nutrients in the pot, and maintain adequate substrate fertility levels (Biernbaum, 1992). For pine wood substrates, these sustainable practices are not only recommended (Fain et al., 2008; Jackson et al., 2008), but they are also readily attainable (Witcher et al., 2014). Pecan wood substrates are in their infancy, and further exploration is needed. According to the overhead irrigation practices prescribed by Biernbaum (1992), the positive results from our study with $400-\mathrm{N}$ and $25 \%$ wood substitution with leaching fractions of $\approx 20 \%$ could be obtained with $200-\mathrm{N}$ and a leaching fraction of $\approx 10 \%$.

\section{Conclusions}

This study presents positive outcomes for the prospective use of pecan wood chips in greenhouse substrates. Before the potential becomes reality, adjustments to water and fertilizer management are essential. Additional lessons from the pine wood substrate database should also be applied to further research on pecan wood substrates. This research should determine 1) cost-effective ways to process the shredded wood into substrate-useable sizes and shapes, 2) potential for smaller particle sizes to permit use of higher wood proportions but to also enhance microbial degradation, 3) plant 

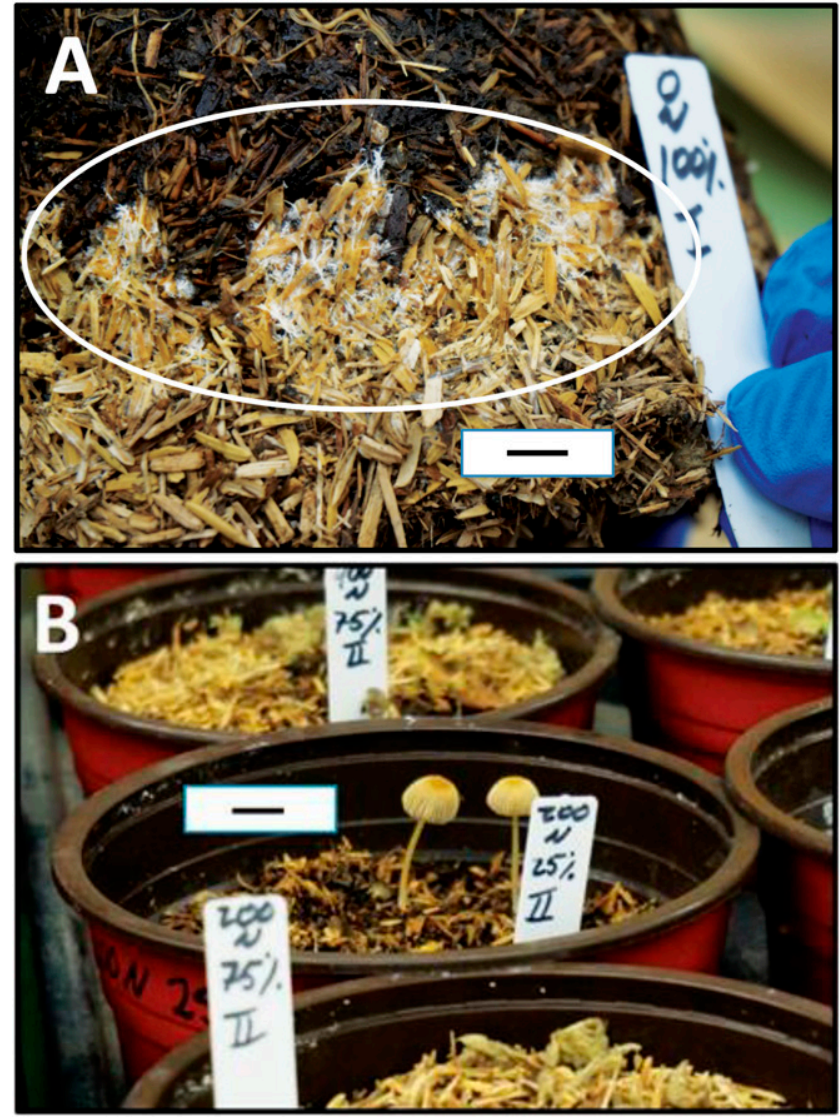

Fig. 2. Images of Pleurotus sp. fungal activity at 60-d root harvest of 'Carpino' garden chrysanthemum. Horizontal scale lines $\approx 1 \mathrm{~cm}$. (A) Mycelia growth is circumscribed in white for a pot replication containing $100 \%$ pecan wood chips substituting for peatmoss. (B) Center of image shows aboveground fruiting bodies from one of the $25 \%$ pecan wood substitution pot replications. Substrate details in Table 1.

and substrate performance over longer durations, 4) optimal limestone incorporation rates, 5) costs and returns with regional wood supplies and demands of pecan and greenhouse growers, and 6) growth responses of other ornamental crop species.

\section{Literature Cited}

Biernbaum, J.A. 1992. Root-zone management of greenhouse container-grown crops to control water and fertilizer use. HortTechnology 2: $127-132$

Borazjani, A., C.H. Graves, Jr., and P.A. Hedin 1985. Occurrence of juglone in various tissues of pecan and related species. Phytopathology 12:1419-1421.

Boyer, C.R., T.V. Gallagher, C.H. Gilliam, G.B Fain, H.A. Torbert, and J.L. Sibley. 2012a. Description of clean chip residual forest harvest and its availability for horticultural uses in the southeastern United States. HortTechnology 22:381-387.

Boyer, C.R., H.A. Torbert, C.H. Gilliam, G.B Fain, T.V. Gallagher, and J.L. Sibley. 2012b. Nitrogen immobilization in plant growth substrates: Clean chip residual, pine bark, and peat moss. Intl. J. Agron. doi:10.1155/2012/978528.

Cavins, T.J., B.E. Whipker, W.C. Fonteno, B. Harden, I. McCall, and J.L. Gibson. 2000. Monitoring and managing $\mathrm{pH}$ and $\mathrm{EC}$ using the pourthru extraction method. North Carolina State Univ. Hort. Info. Lflt. 590.
Cook, R.D. and S. Weisberg. 1982. Residuals and influence in regression. Chapman and Hall, New York, NY.

Dole, J.M. and H.F. Wilkins. 2005. Floriculture: Principles and species. 2nd ed. Pearson Education, Inc., Upper Saddle River, NJ.

Fain, G.B., C.H. Gilliam, J.L. Sibley, and C.R Boyer. 2008. WholeTree substrates derived from three species of pine in production of annual vinca. HortTechnology 18:13-17.

Fisher, P.R., W.R. Argo, and J.A. Biernbaum. 2014. Validation of a fertilizer potential acidity model to predict the effects of water-soluble fertilizer on substrate $\mathrm{pH}$. HortScience 49:10611066.

Gaches, W.G., G.B. Fain, D.J. Eakes, C.H. Gilliam, and J.L. Sibley. 2011. Comparison of aged and fresh WholeTree as a substrate component for production of greenhouse-grown annuals. J. Environ. Hort. 29:39-44.

Grauke, L.J. and T.E. Thompson. 1996. Pecans and hickories, p. 185-239. In: J. Janick and J.N. Moore (eds.). Fruit breeding. Wiley, New York, NY.

Griffin, D.H. 1994. Fungal physiology. 2nd ed. Wiley-Liss, Inc., New York, NY.

Horneck, D.A. and R.O. Miller. 1998. Determination of total nitrogen in plant tissue, p. $75-84$. In: Y.P. Karla (ed.). Handbook of reference methods for plant analysis. CRC Press, Boca Raton, FL.

Jackson, B.E., R.D. Wright, J.F. Browder, J.R Harris, and A.X. Niemiera. 2008. Effect of fertilizer rate on growth of azalea and holly in pine bark and pine tree substrates. HortScience 43:1561-1568.

Jackson, B.E., R.D. Wright, and N. Gruda. 2009 Container medium $\mathrm{pH}$ in a pine tree substrate amended with peatmoss and dolomitic limestone affects plant growth. HortScience 44:1983-1987.

Kallestad, J.C., J.G. Mexal, and T.W. Sammis 2008. Mesilla valley pecan orchard pruning residues: Biomass estimates and value-added opportunities. New Mexico Agr. Expt. Sta. Res. Rpt. 764.

Kuack, D. 2014. Peatmoss may be in short supply this year. Greenhouse Grower 32(13):24-28.

Lillywhite, J.M., T.L. Crawford, J. Libbin, and J. Peach. 2007. New Mexico's pecan industry: Estimated impacts on the state's economy. New Mexico Agr. Expt. Sta. Bul. 791.

Miller, R.O. 1998. Nitric-perchloric acid wet digestion in an open vessel, p. 57-62. In: Y.P. Karla (ed.). Handbook of reference methods for plant analysis. CRC Press, Boca Raton, FL.

Murphy, A.M., C.H. Gilliam, G.B. Fain, H.A Torbert, T.V. Gallagher, J.L. Sibley, and C.R. Boyer. 2011. Low-value trees as alternative substrates in greenhouse production of three annual species. J. Environ. Hort. 29:152-161.

Nau, J. (ed.). 2011. Ball redbook. 18th ed. Vol. 2. Crop production. Ball Publishing, West Chicago, IL.

Nelson, P.V. 2012. Greenhouse operation and management. 7th ed. Prentice Hall, New York, NY.

Paparozzi, E.T. 2003. Nutrition of floricultural crops: How far have we come? HortScience 38:1031-1035.

Pettersen, R.C. 1984. The chemical composition of wood, p. 57-126. In: R.M. Rowell (ed.). The chemistry of solid wood. Adv. Chem. Ser. 207. American Chemical Society, Washington, DC.

Picchioni, G.A., S.A. Weinbaum, D.L. Daniel, and H. Karaca. 2000a. Biological and practical importance of light microenvironments in a tree: Participatory research to match teaching and learning styles. J. Nat. Resour. Life Sci. Educ. 29:78-87.

Picchioni, G.A., H. Karaca, L.G. Boyse, B.D McCaslin, and E.A. Herrera. 2000b. Salinity, boron, and irrigated pecan productivity along New Mexico's Rio Grande basin. J. Environ. Qual. 29:955-963.

Picchioni, G.A., J. Ruiz, R.M. Goss, and J.G. Mexal. 2014. Nursery crop growth response to municipal biosolids: Species salt and xeric adaptation a key factor? Compost Sci. Util. 22:138-152

Ritz, K. and I.M. Young. 2004. Interactions between soil structure and fungi. Mycologist 18:52-59.

Schachtman, D.P., R.J. Reid, and S.M. Ayling. 1998. Phosphorus uptake by plants: From soil to cell. Plant Physiol. 116:447-453.

Still, S., J.B. Gartner, and T.D. Hughes. 1972. Effect of sawdust age and nitrogen application on chrysanthemums grown in white oak sawdust media. Forest Prod. J. 22:111114.

Tahboub, M.B., W.C. Lindemann, and L. Murray. 2007. Nutrient availability in soil amended with pecan wood chips. HortScience 42:339343.

Tahboub, M.B., W.C. Lindemann, and L. Murray. 2008. Chemical and physical properties of soil amended with pecan wood chips. HortScience 43:891-896

Taylor, L.L., A.X. Niemiera, R.D. Wright, and J.R. Harris. 2012. Storage time and amendments affect pine tree substrate properties and marigold growth. HortScience 47:1782-1788. 
U.S. Department of Agriculture. 2015a. Census of agriculture. 17 July 2015 . $<$ http://www.agcensus. usda.gov/publications $>$.

U.S. Department of Agriculture-NASS. 2015b. Noncitrus fruits and nuts 2014 summary. 17 July 2015. <http://www.nass.usda.gov>.

U.S. Forest Service. 2015. Forestry images. 1 Sept. 2015. <http://www.forestryimages.org/browse/ detail.cfm?imgnum $=3046070>$.

Wang, J., R. Krishna, J. Yang, K.P.R. Dandamudi, and S. Deng. 2015. Nitrogen-doped porous carbons for highly selective $\mathrm{CO}_{2}$ capture from flue gases and natural gas upgrading. Materials Today Communications 4:156-165.

Wilson, J.B. 1988. A review of evidence on the control of shoot:root ratio, in relation to models. Ann. Bot. (Lond.) 61:433-449.

Witcher, A.L., E.K. Blythe, G.B. Fain, and K.J. Curry. 2014. Stem cutting propagation in pine tree substrates. HortTechnology 24:30-37.

Wood, B.W. and D. Stahmann. 2004. Hedge pruning pecan. HortTechnology 14:63-72.
Wright, R.D. and J.F. Browder. 2005. Chipped pine logs: A potential substrate for greenhouse and nursery crops. HortScience 40:1513-1515.

Wright, R.D., J.F. Browder, and B.E. Jackson. 2006. Ground pine chips as a substrate for containergrown woody nursery crops. J. Environ. Hort. 24:181-184

Wright, R.D., B.E. Jackson, J.F. Browder, and J.G. Latimer. 2008. Growth of chrysanthemum in a pine tree substrate requires additional fertilizer. HortTechnology 18:111-115. 